\title{
Aplikasi Strategi Pemilihan Pemain Futsal Menggunakan Metode Electre
}

\author{
Ema Kurnia, Muhammad Ferly Ogianta \\ Program Studi Sistem Informasi, Program Diploma Universitas Pakuan \\ Program Studi IImu Komputer, Fakultas Matematika dan IImu Pengetahuan Alam \\ Universitas Pakuan \\ Jl. Pakuan P.O. Box. 452 Bogor \\ ema.kurnia@unpak.ac.id
}

\begin{abstract}
Abstrak
Pelatih dalam olahraga futsal memiliki peranan penting bagi kemajuan tim futsal, untuk mencetak pemain yang baik maka diperlukan kemampuan khusus yang dimiliki pelatih. Dalam proses penyeleksian calon pemain, seorang pelatih dituntut untuk mendapatkan pemain yang berkualitas. Penerapan Sistem Penunjang Keputusan (SPK), dimana sistem penunjang keputusan dibangun untuk mendukung solusi atas suatu masalah atau mengevaluasi suatu peluang. Aplikasi ini dirancang dengan menggunakan metode Elimination Et Choix Traduisant La Realite (Electre). Metode electre dapat digunakan pada kondisi dimana alternatif yang kurang sesuai dengan kriteria akan di eliminasi sehingga alternatif yang sesuai dapat dihasilkan. Uji coba validasi dilakukan untuk melihat keakuratan data sistem dengan data aktual pakar, sistem ini menghasilkan keakuratan data sebesar $81.82 \%$, dan hasil dari penelitian ini adalah merekomendasikan calon pemain futsal berdasarkan kategori posisi kepada pelatih sehingga mempermudah dan mempersingkat waktu dalam melakukan penyeleksian calon pemain tim futsal.
\end{abstract}

Kata Kunci: SPK, Futsal, Electre

\section{Abstract}

The coach in futsal has an important role in the progress of the futsal team, in order to make good players, special skills are needed by the coach. In the process of selecting potential players, a coach is required to get quality players. By implementing a Decision Support System (DSS), where a decision support system is built to support a solution to a problem or evaluate an opportunity. This application was designed using the Elimination Et Choix Traduisant La Realite (Electre) method. The electre method can be used in conditions where alternatives which do not meet the criteria are eliminated and suitable alternatives can be produced. Validation testing of the system was done to see the data accuracy with the actual data of experts, this system produces data accuracy of $81.82 \%$, and the results of this study are recommending prospective futsal players based on position categories to the coach to simplify and shorten the time in selecting prospective futsal team players

Keywords : DSS, Futsal, Electre

\section{Pendahuluan}

Olahraga futsal telah ikut berperan dalam mengharumkan nama daerah, bangsa dan negara. Baik melalui kompetisi di tingkat daerah, nasional maupun internasional. Seiring dengan tuntutan kompetisi diberbagai tingkat nasional maupun internasional, pelatih dituntut untuk menyiapkan pemainnya untuk dapat berlaga dikompetisi.

Pelatih memegang peranan penting bagi kemajuan tim, untuk mencetak pemain yang baik maka diperlukan kemampuan khusus yang dimiliki pelatih. Banyaknya pemain dari berbagai tim futsal, keterampilan pelatih sangat diperlukan untuk melakukan penyeleksian pemain. Proses penyeleksian pemain ini membutuhkan ketajaman dan kejelian guna mendapatkan pemain yang berkualitas. Proses seleksi pemain masih menjadi kendala bagi pelatih karena belum mampu 
menilai pemain secara objektif. Proses pengambilan keputusan dalam menentukan pemain masih mengandalkan insting pelatih. Selain itu proses manual membutuhkan waktu yang cukup lama dan kecermatan yang lebih dalam pemilihan pemain. Untuk memecahkan masalah-masalah tersebut perlu adanya solusi yang dibuat dengan teknologi informasi yang berkembang pesat saat ini, pengelolaan teknologi dalam dunia olahraga sangat dibutuhkan. Penggunaan teknologi pengambilan keputusan ini bertujuan untuk membantu memutuskan atau menentukan pilihanpilihan berdasarkan kriteria yang dipilih pelatih guna menentukan pemain.

Penerapan Sistem Pendukung Keputusan (SPK), dimana sistem pendukung keputusan dibangun untuk mendukung solusi atas suatu masalah atau mengevaluasi suatu peluang [1]. Metode pengambilan keputusan yang digunakan dalam pengambilan keputusan adalah metode Elimination Et Choix Traduisant La Realite (Electre). Metode electre sendiri merupakan salah satu metode yang efektif untuk MADM (Multiple Attribute Decision Making) dengan fitur kualitatif dan kuantitatif, sehingga dapat meningkatkan kemampuan dalam membuat keputusan [2]. Penggunaan metode electre untuk memberikan rekomendasi pemain dengan kriteria yang telah ditentukan diharapkan dapat menghasilkan keputusan rekomendasi terbaik sesuai keinginan pelatih olahraga futsal. Adapun manfaat secara umum pada penelitian ini adalah dengan adanya teknologi pengambilan keputusan dalam dunia olahraga diharapkan mampu mendukung dan mempermudah kinerja pelatih dalam menentukan pemain sebagai tahap awal dalam perancangan strategi tim serta diharapkan mampu menghasilkan pemain-pemain yang handal dan berkualitas.

Dasar Teori yang melandari pada penelitian Aplikasi Strategi Pemilihan Pemain Futsal Menggunakan Metode Electre

\subsection{Olahraga Futsal}

Futsal diciptakan di Montevideo, Uruguay pada tahun 1930, oleh Juan Carlos Ceriani. Futsal berasal dari bahasa spanyol, yaitu futbol (Sepak Bola) dan sala (Ruangan), yang jika digabung artinya menajadi "Sepak Bola dalam ruangan". Futsal hampir sama dengan sepak bola, yaitu dimainkan oleh dua tim, tujuannya juga sama yaitu memasukkan bola kedalam gawang lawan, namun bedanya dalam permainan futsal masing-masing tim beranggotakan lima orang dan mempunyai peraturan berbeda, ukuran lapangan lebih kecil, bola lebih kecil dan lama bermain $2 \times 20$ menit [3].

Dalam olahraga futsal terdapat beberapa istilah bagi para pemain futsal, diantaranya yaitu :

1. GoalKeeper (Penjaga Gawang).

GoalKeeper atau Penjaga gawang merupakan salah satu posisi yang memiliki tugas khusus untuk menjaga gawang.

2. Anchor (Pemain Bertahan atau Bek).

Anchor merupakan salah satu posisi dalam futsal yang biasanya berada di depan kipper, yang berperan sebagai pemain bertahan.

3. Flank (Pemain Sayap).

Flank merupakan salah satu posisi dalam futsal yang biasanya berposisi disayap atau samping kanan maupun kiri dan sering menjadi penggerak serangan tim.

4. Pivot (Penyerang).

Pivot merupakan posisi yang berada dibarisan depan sebagai penyerang utama tim.

\subsection{Elimination Et Choix Traduisan La Realite (Electre)}

Sistem Pendukung Keputusan (SPK) atau Decision Support System (DDS) didefinisikan sebagai suatu sistem informasi untuk membantu manajer level menengah untuk proses pengambilan keputusan setengah terstruktur (semi structured) supaya lebih efektif dengan menggunakan model-model analisis dan data yang tersedia [4]. Salah satu metode dalam sistem pengambilan keputusan adalah metode electre. Metode electre merupakan salah satu metode pengambilan keputusan multi-kriteria berdasarkan pada konsep outranking dengan membandingkan pasangan alternatif-alternatif berdasarkan setiap kriteria yang sesuai [5]. Metode electre dapat digunakan pada kondisi dimana alternatif yang kurang sesuai dengan kriteria di eliminasi dan alternatif yang sesuai dapat dihasilkan, dengan kata lain metode electre dapat digunakan untuk kasus-kasus dengan banyak alternatif namun hanya sedikit kriteria yang dilibatkan. 
Konsep dasar metode electre adalah untuk menangani hubungan outrangking dengan menggunakan perbandingan berpasangan antara masing-masing kriteria secara terpisah. Dimisalkan terdapat hubungan outrangking antara Ai dengan Aj yang menjelaskan bahwa ketika alternatif ke-i tidak mendominasi alternatif ke-j secara kuantitatif, maka dapat disimpulkan bahwa Aj hampir lebih baik dari Ai. Suatu alternatif dikatakan mendominasi alternatif yang lainnya jika satu atau lebih kriterianya melebihi (dibandingkan dengan kriteria dari alternatif yang lain) dan sama dengan kriteria lain yang tersisa [6].

Langkah-langkah Metode Electre :

1. Normalisasi matriks keputusan.

Dalam prosedur normalisasi, setiap atribut diubah menjadi nilai yang comparable. Normalisasi dapat dilakukan dengan rumus 1 :

$$
r_{i j}=\frac{x_{i j}}{\sqrt{\sum_{i=1}^{m} x^{2}}}
$$

Dimana, $i=1,2,3 \ldots m$ dan $j=1,2,3 \ldots n$.

2. Pembobotan pada matriks yang telah dinormalisasi.

Setelah dinormalisasi, setiap kolom dari matriks $R$ dikalikan dengan bobot prefrensi $(W)$ yang ditentukan oleh pembuat keputusan. Sehingga, weighted normalized matrix dirumuskan sebagai berikut :

$$
V=R \cdot W
$$

Dimana: $\quad W=$ matriks prefrensi

$R=$ matriks yang telah dinormalisasi

$V=$ matriks hasil perkalian antara matriks pembobotan dan matriks yang telah dinormalisasi

3. Menentukan himpunan concordance dan discordance index.

Untuk setiap pasangan dari alternatif $k$ dan $I(k, I=1,2,3 \ldots m$ dan $k \neq I)$ kumpulan $J$ kriteria dibagi menjadi dua himpunan, yaitu concordance $(C)$ dan discordance $(D)$. Sebuah kriteria dalam suatu alternatif termasuk concordance jika, record pertama lebih besar dari record kedua maka hasilnya adalah concordance, sebaliknya discordance didapat apabila record pertama dibandingkan dengan record kedua dan hasilnya record kedua lebih besar dari record pertama. Concordance dan discordance didapat berdasarkan rumus berikut:

$$
C_{k l}=\left\{j, v_{k l} \geq v_{i j}\right\}, \text { untuk } j=1,2,3 \ldots n
$$

Discordance :

$$
D_{k l}=\left\{j, v_{k l}<v_{i j}\right\}, \text { untuk } j=1,2,3 \ldots n
$$

4. Menghitung matriks concordance dan discordance.

Menghitung matriks concordance untuk menentukan nilai dari elemen-elemen pada matriks concordance adalah dengan menjumlahkan bobot-bobot yang termasuk pada himpunan concordance, secara matematisnya matriks concordance dapat diformulasikan sebagai berikut :

$$
C_{k l}=\sum_{j \epsilon C_{k l}} w_{j}
$$

Setelah himpunan matriks concordance ditentukan, langkah selanjutnya menentukan matriks discordance. Untuk menentukan nilai dari elemen-elemen pada matriks discordance adalah dengan membagi maksimum selisih kriteria yang termasuk ke dalam himpunan bagian matriks discordance dengan maksimum selisih nilai seluruh kriteria yang ada, diformulasikan sebagai berikut :

Komputasi Vol. 15, No. 2, Juli 2018: $140-194$ 


$$
d_{k l}=\frac{\max \left\{\left|v_{k j}-v_{l j}\right|\right\}_{j \in D_{k l}}}{\max \left\{\left|v_{k j}-v_{l j}\right|\right\}_{\forall j}}
$$

$$
\text { Max = maksimum selisih kriteria }
$$

5. Menentukan matriks dominan concordance dan discordance.

Menghitung matriks dominan concordance. Matriks $\mathrm{F}$ sebagai matriks dominan concordance dapat dibangun dengan bantuan nilai threshold, yaitu dengan membandingkan setiap nilai elemen matriks concordance dengan nilai threshold.

$$
C_{k l} \geq \underline{c}
$$

Nilai threshold diperoleh dari penjumlahan seluruh nilai matriks concordance dibagi dengan jumlah baris matriks dikali dengan jumlah baris matriks dikurangi 1 (satu). Mencari nilai threshold dapat diformulasikan sebagai berikut :

$$
\underline{c}=\frac{\sum_{k=1}^{m} \sum_{l=1}^{m} c_{k l}}{m(m-1)}
$$

Sehingga elemen matriks $\mathrm{F}$ dapat ditentukan sebagai berikut :

$$
f_{k l}=\left\{\begin{array}{l}
1, j i k a C_{k l} \geq \underline{c} \\
0, j i k a C_{k l}<\underline{c}
\end{array}\right.
$$

Menghitung matriks dominan discordance. Matriks $\mathrm{G}$ sebagai matriks dominan discordance dapat dibangun dengan bantuan nilai threshold $\underline{d}$ :

$$
\underline{d}=\frac{\sum_{k=1}^{m} \sum_{l=1}^{m} d_{k l}}{m(m-1)}
$$

dan elemen matriks $\mathrm{G}$ ditentukan sebagai berikut :

$$
g_{k l}=\left\{\begin{array}{lll}
0, j i k a & d_{k l} \geq \underline{d} \\
1, j i k a & d_{k l}<\underline{d}
\end{array}\right.
$$

6. Menentukan aggregate dominance matrix

Matriks E sebagai aggregate dominance matrix adalah matriks yang setiap elemennya merupakan perkalian antara elemen matriks $F$ dengan elemen matriks $G$ yang bersesuaian, secara matematis dapat dinyatakan sebagai berikut :

$$
e_{k l}=f_{k l} \times g_{k l}
$$

7. Eliminasi alternatif yang less favourable

Matriks $\mathrm{E}$ memberikan urutan pilihan dari setiap alternatif, yaitu bila $e_{k l}=1$ maka alternatif $A_{k}$ merupakan alternatif yang lebih baik daripada $A_{1}$. Sehingga, baris dalam matriks $\mathrm{E}$ memiliki jumlah $e_{k l}=1$ paling sedikit dapat di eliminasi, dengan demikian alternatif terbaik adalah alternatif yang mendominasi alternatif lainnya

\section{Metode Penelitian}

2.1 Tahapan Penelitian

Metode Penelitian yang digunakan adalah metode siklus hidup pengembangan sistem atau

System Development Live Cycle (SDLC), meliputi 5 tahapan yaitu [7] :
1. Perencanaan
2. Analisis
3. Perancangan
4. Implementasi
5. Uji Coba 
Gambaran sistem yang akan dikembangkan dapat terlihat pada Diagram Konteks berikut ini [8].

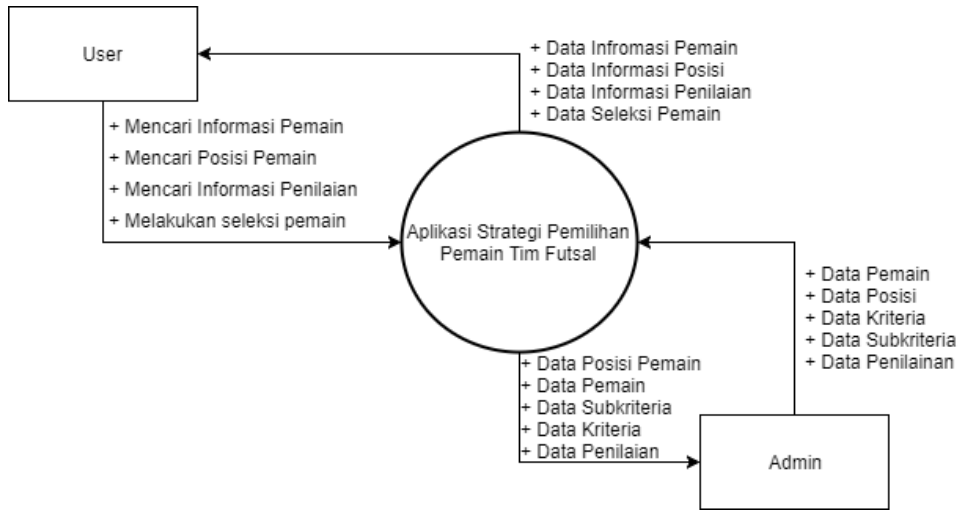

Gambar 1. Diagram Konteks

\section{$2.2 \quad$ Kriteria}

Kriteria didapat berdasarkan hasil wawancara terhadap pelatih. Kriteria ini ditentukan dari

4 (empat) kategori posisi, yaitu :

1. Goalkeeper (Penjaga Gawang)

2. Anchor (Pemain Bertahan)

3. Flank (Pemain Sayap)

4. Pivot (Penyerang)

Sehingga setiap kategori posisi memiliki kriteria tersendiri, yaitu sebagai berikut :

Table 1. Kriteria Posisi

\begin{tabular}{|c|c|}
\hline Posisi & Kriteria \\
\hline \multirow{5}{*}{ Goalkeeper } & Penyelamatan \\
\hline & Sapuan (Clearance) \\
\hline & Interception \\
\hline & Stopping \\
\hline & Konsentrasi \\
\hline \multirow{5}{*}{ Anchor } & Defense \\
\hline & Antisipasi \\
\hline & Control \\
\hline & Strength \\
\hline & Stopping \\
\hline \multirow{5}{*}{ Flank } & Speed \\
\hline & Passing \\
\hline & Control \\
\hline & Movement \\
\hline & Ketenangan \\
\hline \multirow{5}{*}{ Pivot } & Agility \\
\hline & Finishing \\
\hline & Akselerasi \\
\hline & Technique \\
\hline & Body Balance \\
\hline
\end{tabular}

Keterangan :

1. Interception (Penangkapan Bola).

2. Stopping (Menghentikan Bola).

3. Defense (Bertahan).

4. Passing (Mengoper).

5. Control (Mengontrol Bola).

6. Strength (Kekuatan).

7. Speed (Kecepatan).

8. Agility (Kelincahan).

Komputasi Vol. 15, No. 2, Juli 2018 : $140-194$ 
9. Technique (Teknik penguasaan bola).

10. Movement (Pergerakan).

11.Body Balance (Keseimbangan tubuh dalam penguasaan bola).

\subsection{Penentuan Alternatif dan Bobot Kriteria}

Dalam masing-masing kriteria pada setiap posisi, penentuan bobot sub-kriteria dari setiap kriteria ditentukan berdasarkan pelatih menggunakan skala likert. Skala likert digunakan untuk mengukur sikap, pendapat dan persepsi seseorang atau sekelompok orang tentang fenomena sosial. Variable yang diukur menggunakan skala likert dijabarkan menjadi indikator variabel, kemudian indikator tersebut dijadikan sebagai titik ukur untuk menyusun item-item berupa pertanyaan atau pernyataan.

Dalam skala likert, terdapat 2 (dua) bentuk pernyataan yaitu positif yang berfungsi untuk mengukur sikap positif, dan pernyataan negatif berfungsi untuk mengukur sikap negatif. Pengukuran tersebut menghasilkan sebuah interpretasi nilai dalam persentasi yang dicocokkan ke dalam sebuah kategori [9].

Tabel 2. Bobot Sub-Kriteria Goalkeeper

\begin{tabular}{|c|c|c|c|c|}
\hline No & Nama Kriteria & Rentang Nilai & Sub-kriteria & Bobot \\
\hline \multirow{5}{*}{1} & \multirow{5}{*}{ Penyelamatan } & $0-2$ & Sangat Kurang & 1 \\
\hline & & $3-4$ & Kurang & 2 \\
\hline & & $5-6$ & Cukup & 3 \\
\hline & & $7-8$ & Baik & 4 \\
\hline & & $9-10$ & Sangat Baik & 5 \\
\hline \multirow{5}{*}{2} & \multirow{5}{*}{ Sapuan (Clearance) } & $0-2$ & Sangat Kurang & 1 \\
\hline & & $3-4$ & Kurang & 2 \\
\hline & & $5-6$ & Cukup & 3 \\
\hline & & $7-8$ & Baik & 4 \\
\hline & & $9-10$ & Sangat Baik & 5 \\
\hline \multirow{5}{*}{3} & \multirow{5}{*}{ Interception } & $0-2$ & Sangat Kurang & 1 \\
\hline & & $3-4$ & Kurang & 2 \\
\hline & & $5-6$ & Cukup & 3 \\
\hline & & $7-8$ & Baik & 4 \\
\hline & & $9-10$ & Sangat Baik & 5 \\
\hline \multirow{5}{*}{4} & \multirow{5}{*}{ Stopping } & $0-2$ & Sangat Kurang & 1 \\
\hline & & $3-4$ & Kurang & 2 \\
\hline & & $5-6$ & Cukup & 3 \\
\hline & & $7-8$ & Baik & 4 \\
\hline & & $9-10$ & Sangat Baik & 5 \\
\hline \multirow{5}{*}{5} & \multirow{5}{*}{ Konsentrasi } & \multirow{5}{*}{$\begin{array}{l}\text { Keterangan : } \\
\text { Konsentrasi dinilai } \\
\text { berdasarkan mental } \\
\text { pemain dalam } \\
\text { pertandingan }\end{array}$} & Sangat Kurang & 1 \\
\hline & & & Kurang & 2 \\
\hline & & & Cukup & 3 \\
\hline & & & Baik & 4 \\
\hline & & & Sangat Baik & 5 \\
\hline
\end{tabular}

Dalam penilaian terhadap calon pemain, rentang nilai diberikan sebagai acuan dalam penentuan penilaian dengan melakukan uji coba atau pelatihan untuk mendapatkan nilai dari masing-masing calon pemain yang dinilai langsung oleh pelatih, sehingga nantinya dapat dilakukan penyeleksian terhadap calon pemain.

\section{Hasil dan Pembahasan}

Aplikasi ini dirancang untuk dapat memudahkan pelatih tim futsal dalam menyeleksi calon pemain, dengan melakukan pemilihan pemain berdasarkan kategori posisi. Pelatih dapat langsung melakukan penyeleksian terhadap calon pemain yang sudah terdaftar. Pada saat penyeleksian, setiap pemain sudah memiliki nilai penilaian masing-masing, penilaian setiap pemain ini didapatkan berdasarkan posisi calon pemain, dengan memiliki 5 (lima) kriteria di dalamnya dan terdapat nilai sub-kriteria untuk setiap kriteria, yaitu sangat baik, baik, cukup, kurang dan sangat kurang. Dalam melakukan penyeleksian calon pemain, pengisian nilai bobot kriteria hanya menggunakan angka. Pada proses pengisian nilai bobot kriteria, pelatih dapat memasukkan nilai setiap kriteria sesuai kebutuhan. Proses penyeleksian pemain dilakukan oleh 
pelatih dengan memberikan nilai bobot kriteria untuk kategori posisi goalkeeper yaitu 10,8,9,9,8. Bobot kriteria yang sudah diberikan akan diproses oleh sistem menjadi persentase kemudian dilakukan perhitungan berdasarkan nilai sub-kriteria masing-masing calon pemain dengan menggunakan metode electre.

Pada hasil seleksi calon pemain posisi goalkeeper, system menghasilkan atau merekomendasikan calon pemain dengan ranking 1 (satu) sebagai pemain inti yaitu Fahrurozi AF dengan nilai terbesar 24, dan urutan kedua diisi oleh 2 (dua) calon pemain yaitu Yudo Patio dan Fahril Husaeni dengan total nilai yang sama yaitu 21 seperti tampak pada Gambar 2.

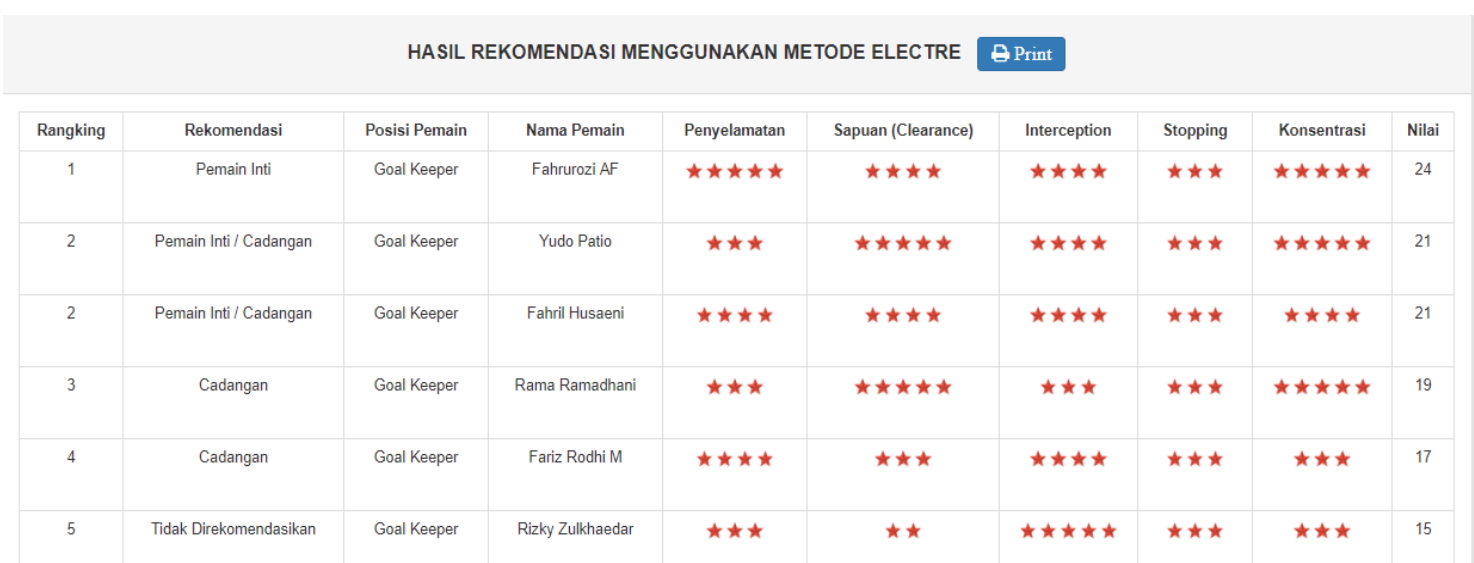

Gambar 2. Hasil seleksi pemain

Berdasarkan hasil grafik pada Gambar 3 terhadap kedua calon pemain yaitu Yudo Patio dan Fahril Husaeni dapat disimpulkan bahwa keduanya mempunyai perbedaan data penilaian yang telah dilakukan saat sesi penilaian calon pemain oleh pelatih yaitu Yudo Patio mempunyai nilai penyelamatan 3 (tiga) sedangkan Fahril Husaeni mempunyai nilai penyelamatan 4 (empat), pada kriteria sapuan dan konsentrasi Yudo Patio lebih unggul dengan memiliki nilai 5 (lima). Sehingga sistem menghasilkan Yudo Patio berada di posisi kedua lebih unggul dari Fahril Husaeni.

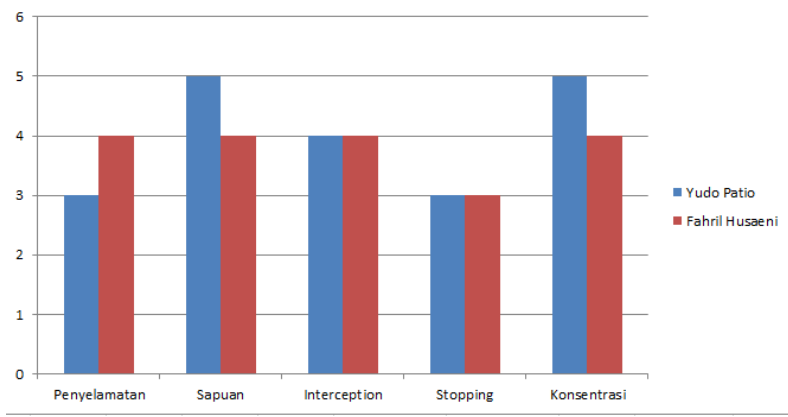

Gambar 3. Grafik Pemain

Berikut grafik yang diperoleh dari 25 calon pemain yang diseleksi berdasarkan kategori posisi goalkeeper.

Komputasi Vol. 15, No. 2, Juli $2018: 140-194$ 


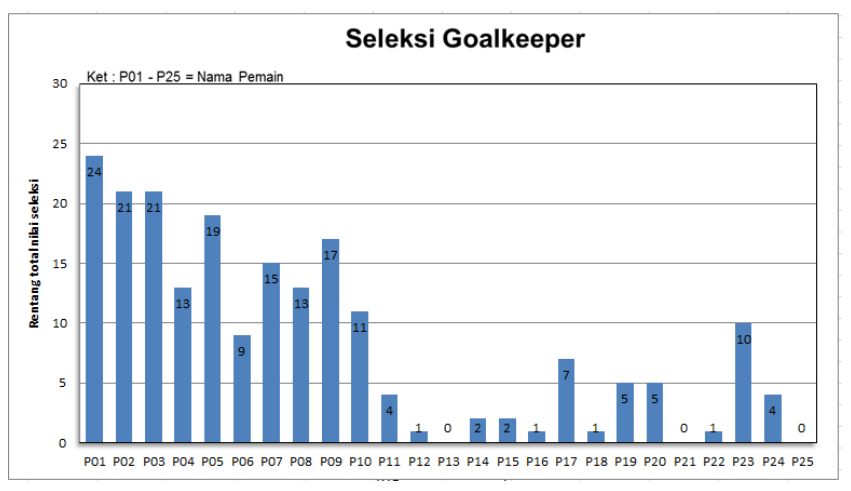

Gambar 4. Grafik Seleksi Goalkeeper

Berdasarkan hasil grafik seperti yang tampil pada Gambar 4, serta perhitungan aplikasi maupun perhitungan manual menggunakan metode electre, Fahrurozi AF (P01) mendominasi agregat matrik calon pemain lain pada posisi goalkeeper berdasarkan nilai bobot kriteria yang telah ditentukan pelatih. Sehingga Fahrurozi AF memperoleh ranking 1 (satu) sebagai rekomendasi pemain inti pada tim futsal dengan total nilai sebesar 24 .

Proses pengurutan nilai ranking setiap calon pemain diperoleh berdasarkan posisi nilai terbesar yang diraih. Dalam penetapan rekomendasi pemain, sistem ini merekomendasikan setiap posisi dengan jumlah 4 (empat) pemain sebagai pemain inti (ranking 1) dan pemain cadangan (raking 2 hingga 4). Sehingga dari hasil rekomendasi yang diberikan oleh sistem, pelatih dapat langsung menentukan pemain inti dan pemain cadangan dalam tim. Hasil dari perhitungan ini menampilkan nilai terbesar hingga nilai terkecil. Aplikasi ini dapat memberikan hasil rekomendasi yang sesuai sehingga mempermudah dan mempersingkat penyeleksian calon pemain.

Validasi merupakan pemeriksaan keakuratan hasil data yang diperoleh pada sistem dengan data aktual yang dimiliki pelatih saat ini. Pada tahap pemeriksaan keakuratan data, dilakukan pengisian nilai bobot kriteria terhadap sistem sesuai dengan kebutuhan pelatih. Nilai akhir yang diperoleh dari sistem dengan nilai terbesar atau ranking 1 (satu) direkomendasikan sebagai pemain inti. Berikut tabel uji coba validasi hasil yang diperoleh sistem dengan data aktual pelatih.

Table 3. Uji coba validasi

\begin{tabular}{|l|l|l|l|l|}
\hline Posisi & Nama Pemain & Hasil Sistem & Data Pelatih & Hasil \\
\hline \multirow{5}{*}{ Goalkeeper } & Fahrurozi AF & $\begin{array}{l}\text { Pemain Inti } \\
\text { (Ranking 1) }\end{array}$ & Pemain Inti & Sesuai \\
\cline { 2 - 5 } & Yudo Patio & $\begin{array}{l}\text { Pemain inti / } \\
\text { Cadangan } \\
\text { (Ranking 2) }\end{array}$ & Cadangan & Sesuai \\
\hline \multirow{5}{*}{ Anchor } & M. Ilham & $\begin{array}{l}\text { Pemain Inti } \\
\text { (Ranking 1) }\end{array}$ & Pemain Inti & Sesuai \\
\cline { 2 - 5 } & Rizky Zulkhaedar & $\begin{array}{l}\text { Pemain inti / } \\
\text { Cadangan } \\
\text { (Ranking 2) }\end{array}$ & Cadangan & Sesuai \\
\cline { 2 - 5 } & Alan Alamsah & $\begin{array}{l}\text { Cadangan } \\
\text { (Ranking 3) }\end{array}$ & Cadangan & Sesuai \\
\cline { 2 - 5 } Flank & Tengku Rizal H & $\begin{array}{l}\text { Cadangan } \\
\text { (Ranking 4) }\end{array}$ & Cadangan & Sesuai \\
\hline \multirow{5}{*}{ Rizki Permana } & $\begin{array}{l}\text { Pemain Inti } \\
\text { (Ranking 1) }\end{array}$ & Pemain Inti & Sesuai \\
\cline { 2 - 5 } & Eldi Pramudio & $\begin{array}{l}\text { Pemain Inti } ~ \\
\text { Cadangan } \\
\text { (Ranking 2) }\end{array}$ & Pemain Inti & Sesuai \\
\cline { 2 - 5 } & Fariz Rodhi M & $\begin{array}{l}\text { Cadangan } \\
\text { (Ranking 3) }\end{array}$ & Cadangan & Sesuai \\
\cline { 2 - 5 } & Raden Corefo & $\begin{array}{l}\text { Cadangan } \\
\text { (Ranking 4) }\end{array}$ & Cadangan & Sesuai \\
\hline
\end{tabular}




\begin{tabular}{|l|l|l|l|l|}
\hline \multirow{3}{*}{ Pivot } & Fariz Rodhi M & $\begin{array}{l}\text { Pemain Inti } \\
\text { (Ranking 1) }\end{array}$ & Cadangan & Tidak Sesuai \\
\cline { 2 - 5 } & Insagi Fransis & $\begin{array}{l}\text { Pemain Inti / } \\
\text { Cadangan } \\
\text { (Ranking 2) }\end{array}$ & Pemain Inti & Tidak Sesuai \\
\hline
\end{tabular}

Berdasarkan pemeriksaan keakuratan data terhadap 11 pemain, 5 (lima) diantaranya sebagai pemain inti dan 6 (enam) pemain sebagai pemain pengganti atau cadangan yang telah dilakukan seperti tampak pada Tabel 3, maka diperoleh hasil yang sesuai baik pada posisi goalkeeper hingga flank namun pada posisi pivot diperoleh hasil yang tidak sesuai antara hasil sistem dengan data aktual pelatih. Berdasarkan diskusi dengan pelatih, Insagi Fransis lebih unggul dari Fariz Rodhi M dalam hal penyelesaain akhir ke gawang lawan (Finishing) sehingga pelatih memilih Insagi Fransis sebagai pemain inti. Hasil keakuratan data yang diperoleh berdasarkan hasil sistem dengan data aktual pelatih sebesar $81.82 \%$.

\section{Kesimpulan}

Pelatih dalam olahraga futsal memiliki peranan penting bagi kemajuan tim futsal, untuk mencetak pemain yang baik maka diperlukan kemampuan khusus yang dimiliki pelatih. Dalam proses penyeleksian calon pemain, seorang pelatih dituntut untuk mendapatkan pemain yang berkualitas maka Sistem Penunjang Keputusan (SPK) dibangun untuk mendukung solusi atas suatu masalah atau mengevaluasi suatu peluang.

Aplikasi strategi pemilihan pemain futsal ini dirancang dengan menggunakan metode Elimination Et Choix Traduisant La Realite (Electre). Metode electre dapat digunakan pada kondisi dimana alternatif yang kurang sesuai dengan kriteria di eliminasi dan alternatif yang sesuai dapat dihasilkan. Aplikasi ini dirancang dengan menerapkan siklus hidup pengembangan sistem yaitu System Development Live Cycle (SDLC) dengan melalui serangkaian tahap mulai dari perancangan database hingga perancangan metode electre guna menghasilkan indentifikasi awal sistem dan selanjutnya di implementasikan kedalam sebuah sistem.

Pada aplikasi ini terdapat 4 (empat) kategori posisi yaitu goalkeeper, anchor, flank dan pivot. Dimana setiap posisi memiliki calon pemain dengan 5 (lima) penilaian berdasarkan kriteria yang berbeda berdasarkan kategori posisi. Didalam aplikasi ini pun terdapat 2 (dua) pengguna yaitu admin dan user, dimana admin bertugas untuk mengatur seluruh konten baik halaman admin maupun halaman utama website mulai dari data pemain hingga data penilaian. Sehingga user dalam hal ini pelatih, dapat langsung melakukan penilaian dengan memasukkan nilai bobot kriteria yang diinginkan serta dapat langsung mengambil data dalam bentuk cetak/print out tanpa harus melakukan penulisan secara manual. Hasil dari penelitian ini adalah merekomendasikan calon pemain futsal berdasarkan kategori posisi kepada pelatih sehingga mempermudah dan mempersingkat waktu dalam melakukan penyeleksian calon pemain tim futsal.

\section{References}

[1] Turban, E, 2005,Decision Support Systems and Intelligent SystemsEdisi Bahasa Indonesia Jilid 1, Andi,Yogyakarta.

[2] C.H. Chen, W.C. Huang. 2005. Using The Electre II Method to Apply and Analyze The Differentiation Theory. Proceding of The Eastern Asia Society for Transportation Studies, Vol. 5., pp. 2237-2249.

[3] Murhananto, 2008. Dasar-dasar Permainan Futsal. Penerbit Kawan Pustaka, Jakarta Selatan.

[4] Jogiyanto. 2005. Sistem Teknologi Informasi. Edisi II. Andi Offset. Yogyakarta.

[5] Janco, Wolfgang \& Bernoider Edward. 2005. Multi-Criteria Decision Making An Application Study Of ELECTRE \& TOPSIS. Dalam Fuzzy Multi-Atribute Decision Making (FUZZY MADM). Graha IImu. Yogyakarta.

[6] Kusumadewi, Sri., Hartati, Sri., Harjoko, Agus., dan Wardoyo, Rentyanto. 2006. Fuzzy Multi Attribute Decision Making (Fuzzy MADM). Graha Ilmu. Yogyakarta.

[7] Kumar, S., Dubey, P. 2013. Software Development Life Cycle (SDLC) Analytical Comparison and Survey on Traditional and Agile Methodology. National Monthly Refereed Journal Of Research In Science \& Technology Volume No.2, Issue No.8 
[8] Agus Winarno. (2007). Analisa \& Perancangan Sistem Informasi. Yogyakarta.Universitas GajahMada.

[9] Bertram D. 2016. "Likert Scales." Retrieved July 18, 2016 from: http://my.ilstu.edu/ eostewa/497/Likert\%20topic-dane-likert.pdf. 